\title{
Strates
}

STRATES Matériaux pour la recherche en sciences sociales

$1 \mid 1986$

Mélanges

\section{Bibliographie : Emploi et crise des grande métropoles, Londres et New York}

Catherine Rhein

\section{OpenEdition}

1 Journals

Édition électronique

URL : http://journals.openedition.org/strates/354

DOI : $10.4000 /$ strates.354

ISSN : $1777-5442$

Éditeur

Laboratoire Ladyss

Édition imprimée

Date de publication : 1 janvier 1986

ISSN : 0768-8067

Référence électronique

Catherine Rhein, «Bibliographie : Emploi et crise des grande métropoles, Londres et New York »,

Strates [En ligne], 1 | 1986, mis en ligne le 08 décembre 2004, consulté le 08 septembre 2020. URL

http://journals.openedition.org/strates/354 ; DOI : https://doi.org/10.4000/strates.354

Ce document a été généré automatiquement le 8 septembre 2020

Tous droits réservés 


\section{Bibliographie : Emploi et crise des grande métropoles, Londres et New York}

Catherine Rhein 